\title{
Effects of Essential Oils of Elettaria cardamomum Grown in India and Guatemala on Gram-Negative Bacteria and Gastrointestinal Disorders
}

\author{
Aftab Alam ${ }^{1, *}$, Najeeb Ur Rehman ${ }^{2}$ (D), Mohd Nazam Ansari ${ }^{2}(D)$ and Amber Hanif Palla ${ }^{3}$ (D) \\ 1 Department of Pharmacognosy, College of Pharmacy, Prince Sattam Bin Abdulaziz University, \\ Al-Kharj 11942, Saudi Arabia \\ 2 Department of Pharmacology and Toxicology, College of Pharmacy, Prince Sattam Bin Abdulaziz University, \\ Al-Kharj 11942, Saudi Arabia; n_rehman5@hotmail.com (N.U.R.); nazam.ansari@gmail.com (M.N.A.) \\ 3 Department of Basic Medical Sciences (Pharmacology), Salim Habib University, Deh Dih, Korangi Creek, \\ Karachi 74900, Pakistan; amber.palla@shu.edu.pk \\ * Correspondence: a.alam@psau.edu.sa; Tel.: +966-509790901
}

check for

updates

Citation: Alam, A.; Rehman, N.U.; Ansari, M.N.; Palla, A.H. Effects of Essential Oils of Elettaria cardamomum Grown in India and Guatemala on Gram-Negative Bacteria and Gastrointestinal Disorders. Molecules 2021, 26, 2546. https://doi.org/ $10.3390 /$ molecules 26092546

Academic Editor:

Francesca Mancianti

Received: 14 February 2021

Accepted: 25 March 2021

Published: 27 April 2021

Publisher's Note: MDPI stays neutral with regard to jurisdictional claims in published maps and institutional affiliations.

Copyright: (c) 2021 by the authors. Licensee MDPI, Basel, Switzerland. This article is an open access article distributed under the terms and conditions of the Creative Commons Attribution (CC BY) license (https:// creativecommons.org/licenses/by/ $4.0 /)$.

\begin{abstract}
The present study examined the chemical composition and antimicrobial and gastrointestinal activity of the essential oils of Elettaria cardamomum (L.) Maton harvested in India (EC-I) and Guatemala (EC-G). Monoterpenes were present in higher concentration in EC-I (83.24\%) than in EC-G (73.03\%), whereas sesquiterpenes were present in a higher concentration in EC-G $(18.35 \%)$ than in EC-I (9.27\%). Minimum inhibitory concentrations (MICs) of 0.5 and $0.25 \mathrm{mg} / \mathrm{mL}$ were demonstrated against Pseudomonas aeruginosa in EC-G and EC-I, respectively, whereas MICs of 1 and $0.5 \mathrm{mg} / \mathrm{mL}$ were demonstrated against Escherichia coli in EC-G and EC-I, respectively. The treatment with control had the highest kill-time potential, whereas the treatment with oils had shorter kill-time. EC-I was observed to be more potent in the castor oil-induced diarrhea model than EC-G. At 100 and $200 \mathrm{mg} / \mathrm{kg}$, P.O., EC-I exhibited $40 \%$ and $80 \%$ protection, respectively, and EC-G exhibited $20 \%$ and $60 \%$ protection, respectively, in mice, whereas loperamide $(10 \mathrm{mg} / \mathrm{kg}$, i.p., positive control) exhibited $100 \%$ protection. In the in vitro experiments, EC-I inhibited both carbachol $(\mathrm{CCh}, 1 \mu \mathrm{M})$ and high $\mathrm{K}^{+}(80 \mathrm{mM})$-induced contractions at significantly lower concentrations than EC-G. Thus, EC-I significantly inhibited P. aeruginosa and E. coli and exhibited more potent antidiarrheal and antispasmodic effects than EC-G.
\end{abstract}

Keywords: Elettaria cardamomum; GC-MS; essential oil; antibacterial; antidiarrheal; antispasmodic

\section{Introduction}

E. cardamomum (L.) Maton, belonging to the Zingiberaceae family (local name: cardamom), is an expensive and commercially significant spice that is in demand worldwide. Although it is native to India and Sri Lanka, it is also grown in Guatemala, Thailand, El Salvador, Malay Archipelago, Vietnam, Papua New Guinea, Cambodia, Laos, and Tanzania, with Guatemala being the largest producer of E. cardamomum in the world [1,2].

Volatile oils were demonstrated to be good sources of bioactive compounds, in the form of cyclic and acyclic, non-oxygenated or oxygenated hydrocarbons of monoterpenes, sesquiterpenes, and diterpenes. It is used in the treatment of several disease conditions such relieving pain, wound, nausea, and cancer lesions in folk medicine [3]. The composition of essential oil depends on the family, genus, species, and chemotype of a plant, as well as from the material which it is obtained, growing conditions, harvesting season and geographical origin [4]. Biological activity of E. cardamomum essential oil is strictly linked to their chemical composition such as ester $\alpha$-terpinyl acetate and monoterpene 1,8cineole, $\alpha$-terpineol, linalool, $\alpha$-pinene, and several others [5]. International organisation for standardization (ISO) developed ISO 4733:2004 oil of cardamom [Elettaria cardamomum (L.) Maton] standard; the data clearly reflect the percentage of the major components of 
the essential oil in different batches of seeds [6]. A wide range of aromatic plants or its parts have been explored for the presence of volatile compounds and evaluated for the antibacterial, antifungal, and antiviral effects [7]. Owing to their biological activities and distinctive flavor and fragrance possessions, essential oils have excellent business potential on the global market due to high demands in cosmetics, pharmaceuticals, food products industries, and traditional medicine [8,9]. Not only cardamom oil, but also its extracts have promising potential for being used as preservatives in the food industry, owing to their antibacterial and flavoring properties, and are considered as preferred alternative to synthetic compounds [10].

E. cardamomum oil is known for its characteristic aroma and is widely used in the food and cosmetic industries as a flavoring and fragrance agent. It is an intestinal smooth muscle relaxant [11] and has exhibited antispasmodic, antidiarrheal, and antibacterial activities [12,13]. The antibacterial effect of essential oil of E. cardamomum against several Gram-negative bacteria [14] such as Escherichia coli and Pseudomonas aeruginosa has been reported. E. coli commonly resides in human colon and frequently causes diarrhea [15], whereas P. aeruginosa also causes diarrhea, and it may effect immune-deficient or antibiotic-treated individuals, which is difficult to treat due to its innate resistance to several antibiotics [16-18]. P. aeruginosa transmitted through the food chain may cause gastrointestinal infections [19]. Hence, both of these organisms directly or indirectly are potentially involved in the etiology of diarrhea.

Contradictory reports exist on the efficacy of E. cardamomum against both these bacteria. Few studies have reported its efficacy against E. coli but not against $P$. aeruginosa [20], whereas another study has reported its efficacy against $P$. aeruginosa, but not against E. coli [21].

These differences could be attributed to the variability or differences in solvent extraction. Therefore, comparative studies of different species must be conducted not only to understand their full potential as herbs but also to identify the most preferable species, because cardamom growing in a specific region provides more health benefits than those growing in other regions. Additionally, a number of these activities have been tested in aqueous methanolic extracts rather than essential oils, which may exhibit different activities depending on the constituents eluted. Therefore, the present study attempted to compare the chemical composition and antimicrobial activity of the essential oil of Guatemalan and Indian E. cardamomum against E. coli and P. aeruginosa and to explore the in vivo antidiarrheal effect and in vitro antispasmodic activity of the two oils to clarify differences in their medicinal properties.

\section{Results}

\subsection{Compositions of the Essential Oils}

Table 1 presents the compositions of the essential oils of EC-I and EC-G capsules identified through GC-MS. About 52 and 63 constituents were identified in the essential oils obtained from EC-I and EC-G, respectively. Total ion-current chromatograms of the typical essential oil (EC-I and EC-G) are shown in Figure 1.

Table 1. Metabolite identified in the essential oils of Guatemala and Indian E. cardamomum using GC-MS.

\begin{tabular}{ccccc}
\hline \multirow{2}{*}{ No } & \multirow{2}{*}{ RT } & \multicolumn{2}{c}{ \% Area E. cardamomum } & \multirow{2}{*}{ Compositions } \\
\cline { 3 - 5 } & & EC-G & EC-I & Monoterpenes Hydrocarbons (MTH) \\
\hline & & & Mhellandrene \\
\hline 1 & 5.436 & 0.43 & 0.72 & Camphene \\
\hline 2 & 5.859 & 0.09 & 0.13 & $\beta$-Phellandrene \\
\hline 3 & 6.296 & 2.22 & 3.74 & Sabinene \\
\hline 4 & 6.365 & 0.66 & 1.03 & $\beta$-Pinene \\
\hline 5 & 6.543 & 2.13 & 3.46 &
\end{tabular}


Table 1. Cont.

\begin{tabular}{|c|c|c|c|c|}
\hline \multirow{2}{*}{ No } & \multirow{2}{*}{ RT } & \multicolumn{2}{|c|}{ \% Area E. cardamomum } & \multirow{2}{*}{ Compositions } \\
\hline & & EC-G & EC-I & \\
\hline 6 & 6.995 & 1.4 & 0.06 & $(+)$-2-Carene \\
\hline 7 & 7.216 & 1.36 & 1.77 & DL-Limonene \\
\hline 8 & 7.515 & 2.01 & 2.95 & $\beta$-cis-Ocimene \\
\hline 9 & 7.738 & 1.23 & 1.51 & $\gamma$-Terpinen \\
\hline 10 & 8.172 & 1.22 & 2.80 & $\alpha$-Terpinene \\
\hline 11 & 8.595 & 0.2 & - & $\beta$-Myrcene \\
\hline 12 & 10.686 & 3.21 & 2.89 & $\beta$-trans-Ocimene \\
\hline \multicolumn{5}{|c|}{ Monoterpenes oxygenated (MTO) } \\
\hline 13 & 7.478 & 10.59 & 14.03 & 1,8-Cineole \\
\hline 14 & 7.918 & 0.81 & - & Dihydrocarveol \\
\hline 15 & 7.921 & - & 1.25 & trans-Sabinenhydrate \\
\hline 16 & 8.407 & 5.51 & 2.63 & Linalool \\
\hline 17 & 8.798 & 0.79 & 0.94 & $\alpha$-Terpinenol \\
\hline 18 & 9.166 & 0.2 & - & cis-verbenol \\
\hline 19 & 9.58 & 0.96 & - & $\alpha$-Phellandren-8-ol \\
\hline 20 & 9.737 & 3.45 & 3.53 & Terpinen-4-ol \\
\hline 21 & 9.978 & 3.45 & 5.11 & $\beta$-Fenchyl alcohol \\
\hline 22 & 10.054 & 0.21 & 0.49 & $n$-Nonyl acetate \\
\hline 23 & 10.121 & - & 0.08 & trans-Pipertiol \\
\hline 24 & 10.158 & 0.88 & - & Verbenone \\
\hline 25 & 10.335 & 1.88 & 0.31 & Citral \\
\hline 26 & 10.859 & 4.00 & 3.55 & cis-Geraniol (Nerol) \\
\hline 27 & 11.218 & 0.35 & 0.23 & Borneyl acetate \\
\hline 28 & 11.357 & 0.65 & 0.12 & 4-Terpinenyl acetate \\
\hline 29 & 11.501 & - & 0.2 & $\begin{array}{l}\text { Bicyclo [4.1.0]heptan-3-ol, 4,7,7-trimethyl-, } \\
\text { (1.alpha.,3.beta.,4.beta.,6.alpha.)- }\end{array}$ \\
\hline 30 & 11.607 & 0.85 & 0.58 & Ocimenyl acetate \\
\hline 31 & 11.743 & 1.40 & - & Thymol \\
\hline 32 & 12.389 & 18.71 & 24.65 & $\alpha$-terpinyl acetate \\
\hline 33 & 12.53 & 1.93 & 2.52 & cis-Geranyl acetate \\
\hline 34 & 22.385 & 0.25 & - & Myrtanol \\
\hline \multicolumn{5}{|c|}{ Sesquiterpenes hydrocarbons (STH) } \\
\hline 35 & 12.769 & 0.44 & 0.29 & $\beta$-Eelemene \\
\hline 36 & 13.335 & 0.96 & 0.21 & $\alpha$-Muurolene \\
\hline 37 & 13.933 & 0.99 & 1.58 & D-Germacrene \\
\hline 38 & 14.015 & 1.28 & 0.11 & $\begin{array}{c}\text { Bicyclo[5.2.0]nonane, } \\
\text { 2-methylene-4,8,8-trimethyl-4-vinyl- }\end{array}$ \\
\hline 39 & 14.06 & 3.16 & 1.89 & $\delta$-Guaiene \\
\hline 40 & 14.131 & - & 1.19 & $\alpha$-selinene \\
\hline 41 & 14.906 & - & 0.78 & $\alpha$-caryophyllene \\
\hline
\end{tabular}


Table 1. Cont.

\begin{tabular}{|c|c|c|c|c|}
\hline \multirow{2}{*}{ No } & \multirow{2}{*}{ RT } & \multicolumn{2}{|c|}{ \% Area E. cardamomum } & \multirow{2}{*}{ Compositions } \\
\hline & & EC-G & EC-I & \\
\hline 42 & 15.253 & 0.91 & 0.26 & $\gamma$-Gurjunene \\
\hline 43 & 17.03 & 0.37 & - & Ledene \\
\hline 44 & 19.043 & 0.87 & - & Alloaromadendrene \\
\hline \multicolumn{5}{|c|}{ Oxygenated Sesquiterpenes (OST) } \\
\hline 45 & 13.4 & 0.49 & 0.19 & trans-Caryophyllene oxide \\
\hline 46 & 13.972 & 0.79 & - & $\gamma$-Eudesmol, 10-epi- \\
\hline 47 & 14.821 & 5.00 & 2.29 & D-Nerolidol \\
\hline 48 & 15.684 & 0.25 & - & $\beta$-Spathulenol \\
\hline 49 & 16.01 & 1.15 & - & $\alpha$-Cadinol \\
\hline 50 & 16.31 & 0.41 & - & Longifolenaldehyde \\
\hline 51 & 16.452 & 0.15 & 0.06 & Aromadendrene oxide-(1) \\
\hline 52 & 16.526 & - & 0.12 & trans-Farnesal \\
\hline 53 & 16.823 & 0.3 & $\mathrm{t}$ & cis-Farnesal \\
\hline 54 & 17.822 & 0.29 & 0.14 & Farnesyl acetate \\
\hline 55 & 18.219 & 0.13 & - & Isoaromadendrene epoxide \\
\hline 56 & 19.381 & 0.41 & - & Costunolide \\
\hline \multicolumn{5}{|c|}{ Diterpenes (DT) } \\
\hline 57 & 19.951 & 0.19 & - & Cembrene C \\
\hline 58 & 23.244 & 0.43 & 1.08 & $\alpha$-Springene \\
\hline \multicolumn{5}{|c|}{ Oxygenated diterpenes (ODT) } \\
\hline 59 & 15.108 & 0.27 & - & Kauran-18-al, 17-(acetyloxy)-, (4.beta.)- \\
\hline 60 & 21.797 & 0.14 & - & Thunbergol \\
\hline \multicolumn{5}{|c|}{ Non-terpenes } \\
\hline 61 & 6.42 & 0.18 & $\mathrm{t}$ & 6-Methyl-5-hepten-2-one \\
\hline 62 & 6.775 & 0.31 & 0.29 & Octanal \\
\hline 63 & 8.222 & 0.14 & 0.14 & Benzene, 2-ethenyl-1,3-dimethyl- \\
\hline 64 & 9.32 & 0.16 & 0.16 & Sabine ketone \\
\hline 65 & 9.393 & 0.13 & 0.47 & 1,2-Dimethyl-3,5-divinylcyclohexane \\
\hline 66 & 9.842 & - & 0.25 & cis-4-Decenal \\
\hline 67 & 12.674 & 0.18 & - & Cyclodecene \\
\hline 68 & 12.679 & - & 1.01 & 9,17-Octadecadienal \\
\hline 69 & 13.01 & 0.12 & 0.23 & 1-Decanol acetate \\
\hline 70 & 15.088 & - & 0.31 & 5,7-Dodecadiene, $(Z, Z)$ \\
\hline 71 & 15.534 & 0.42 & - & 7-Heptadecyne, 1-chloro- \\
\hline 72 & 20.153 & 0.27 & 0.44 & Tetracosamethyl-cyclododecasiloxane \\
\hline 73 & 20.827 & 0.91 & 0.48 & Cyclodeca-cyclotetradecene, 14,15-didehydro- \\
\hline 74 & 22.557 & 1.94 & 1.69 & Eicosamethylcyclodecasiloxane \\
\hline
\end{tabular}

RT: Retention time (min) and percentage area based on available libraries (e.g., NIST or Wiley). Others compounds: a: Ketone, b: Aldehyde, c: Ester, d: Alkane, e: Alkene, f: Cycloalkane, g: Benzene, h: Halogen, i: nor isoprenoids, $\mathrm{j}$ : siloxane, $(-)$ : not identified, $(\mathrm{t})$ : trace. 

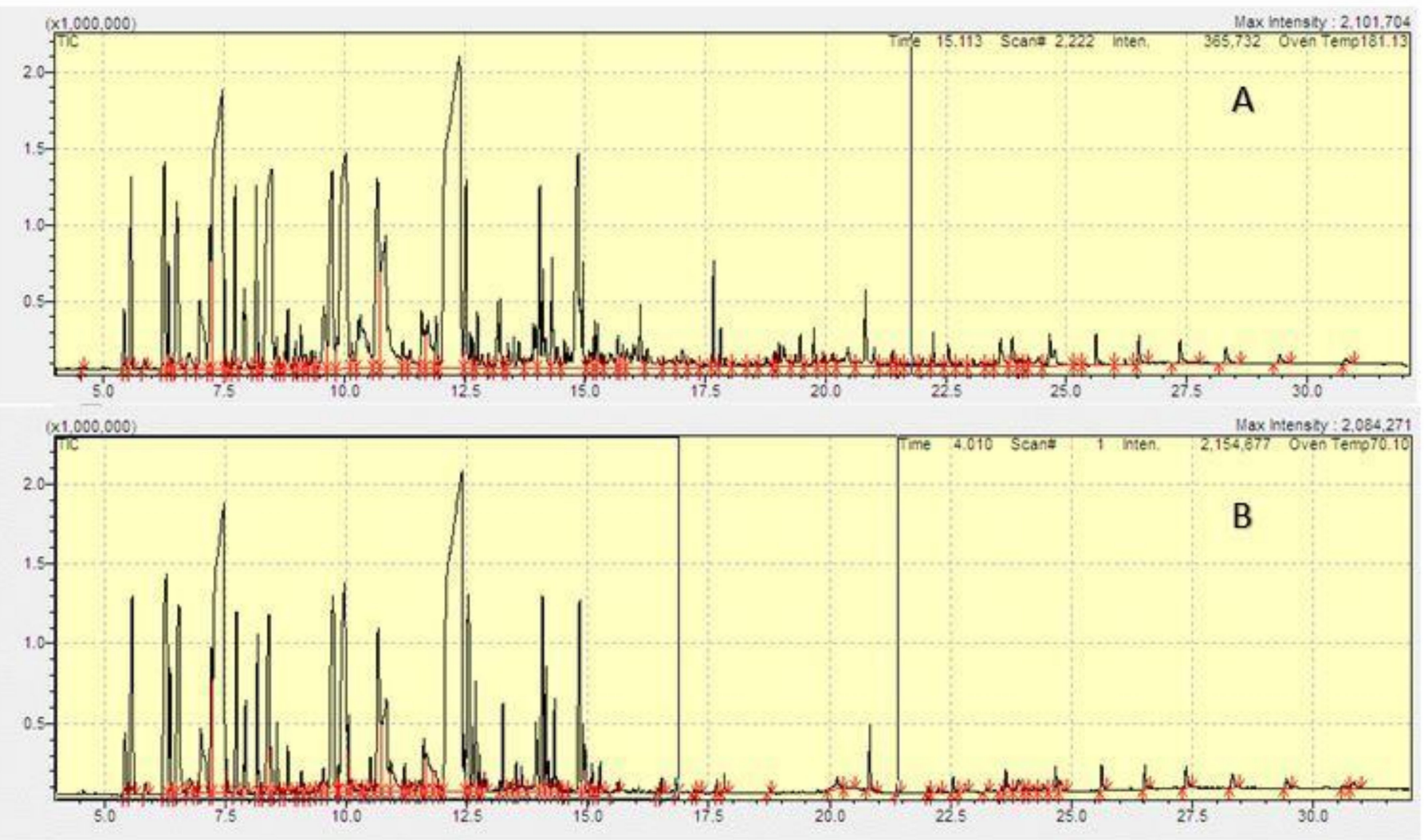

Figure 1. GC-MS chromatograms of Elettaria cardamomum of (A) (Indian, EC-I) and (B) Guatemala, EC-G) essential oils.

The percentage yield of essential oil extracted from EC-I capsules $(4.8 \%)$ was higher than EC-G (3.9\%) capsules. The oxygenated monoterpene and $\alpha$-terpinyl acetate were the main constituents of the essential oils of EC-I (24.65\%) and EC-G $(18.71 \%)$, respectively, whereas 1,8 cineole was identified as the second main volatile constituent, with percentages of $14.03 \%$ and $10.59 \%$, respectively, in EC-I and EC-G essential oils. Phellandrene, $\beta$-pinene, limonene, $\alpha$-terpinene, ocimene, linalool, terpinen-4-ol, $\beta$-fenchyl alcohol, cis-geranyl acetate, guaiene, and nerolidol were identified as other components common to both the samples.

Volatile components were divided into monoterpenes (hydrocarbons and oxygenated), sesquiterpenes (hydrocarbons and oxygenated), diterpenes (hydrocarbons and oxygenated), and non-terpenes, on the basis of their functional groups (Table 2). Out of the total components, approximately $73.03 \%$ and $83.24 \%$ monoterpenes were identified in the essential oil of EC-G and EC-I capsules, respectively.

Table 2. Class of terpene identified in the essential oils obtained from Guatemala and Indian E. cardamoтит.

\begin{tabular}{ccccc}
\hline \multirow{2}{*}{ Terpenes } & \multicolumn{2}{c}{ EC-G } & \multicolumn{2}{c}{ EC-I } \\
\cline { 2 - 5 } & $\begin{array}{c}\text { No. of } \\
\text { Compounds }\end{array}$ & \% Area & $\begin{array}{c}\text { No. of } \\
\text { Compounds }\end{array}$ & \% Area \\
\hline Monoterpenes Hydrocarbons & 12 & 16.16 & 11 & 21.06 \\
\hline Oxygenated monoterpenes & 19 & 56.87 & 17 & 60.22 \\
\hline Total Monoterpenes & 31 & $73.03 \%$ & 28 & $81.28 \%$ \\
\hline Sesquiterpenes Hydrocarbons & 8 & 8.98 & 9 & 6.38 \\
\hline Oxygenated Sesquiterpenes & 11 & 9.37 & 6 & 2.89 \\
\hline Total Sesquiterpenes & 19 & $18.35 \%$ & 14 & $9.27 \%$ \\
\hline
\end{tabular}


Table 2. Cont.

\begin{tabular}{ccccc}
\hline \multirow{2}{*}{ Terpenes } & \multicolumn{2}{c}{ EC-G } & \multicolumn{2}{c}{ EC-I } \\
\cline { 2 - 5 } & $\begin{array}{c}\text { No. of } \\
\text { Compounds }\end{array}$ & \% Area & $\begin{array}{c}\text { No. of } \\
\text { Compounds }\end{array}$ & \% Area \\
\hline Diterpenes hydrocarbons & 2 & 0.62 & 1 & 1.08 \\
\hline Oxygenated diterpenes & 2 & 0.41 & 0 & 0 \\
\hline Total Diterpenes & 4 & $1.03 \%$ & 1 & $1.08 \%$ \\
\hline Non terpenes & 9 & $6.41 \%$ & 10 & 6.09 \\
\hline Total $(75)$ & 63 & 98.82 & 53 & 97.72 \\
\hline
\end{tabular}

Among monoterpenes, approximately $56.87 \%$ and $60.22 \%$ of oxygenated monoterpenes were identified in the EC-G and EC-I oils, respectively, whereas $16.16 \%$ and $21.06 \%$ of monoterpene hydrocarbons were identified in the EC-G and EC-I essential oils, respectively. This analysis represented the chemical difference in the EC-G and EC-I samples.

\subsection{Antimicrobial Activity}

The antibacterial activity of EC-I and EC-G is presented in terms of zone of inhibitions diameters (ZOI, $\mathrm{mm}$ ) and MIC in Table 3.

Table 3. Antimicrobial activity of the essential oils obtained from EC-G and EC-I.

\begin{tabular}{cccccc}
\hline \multirow{2}{*}{ Microorganism } & \multicolumn{2}{c}{ EC-G } & \multicolumn{2}{c}{ EC-I } & Gentamycin (10 $\mu \mathrm{g})$ \\
\cline { 2 - 6 } & ZOI $(\mathbf{m m})$ & $\begin{array}{c}\text { MIC } \\
(\mathbf{m g} / \mathbf{m L})\end{array}$ & ZOI (mm) & $\begin{array}{c}\text { MIC } \\
(\mathbf{m g} / \mathbf{m L})\end{array}$ & ZOI (mm) \\
\hline P. aeruginosa & $12.33 \pm 0.27$ & 0.50 & $16.66 \pm 0.47$ & 0.25 & $22.70 \pm 0.21$ \\
\hline E. coli & $10.13 \pm 0.23$ & 1.00 & $14.40 \pm 0.10$ & 0.50 & $19.67 \pm 0.15$ \\
\hline
\end{tabular}

The ZOI differed marginally with different capsules and microorganisms used in the assay. Both the samples and the standard drug were detected to be inhibitory to $P$. aeruginosa and E. coli, and the EC-I oil was showed to be the most active agent. The MIC of EC-G oil was observed to be 0.5 and $1 \mathrm{mg} / \mathrm{mL}$, whereas that of EC-I was 0.25 and $0.5 \mathrm{mg} / \mathrm{mL}$ against $P$. aeruginosa and E. coli respectively. Thus, the EC-I oil was more active against both the Gram-negative bacteria.

\subsection{Time-Kill Kinetic Assay}

Time-kill assays were performed to explore the cell viability (kill-time) of EC-G and EC-I essential oil, and the results were articulated as a logarithm of viable counts (Figure 2). Non-treated E. coli exhibited growth from 5.24 to $8.32 \log _{10} \mathrm{CFU} / \mathrm{mL}$ and moved into the static phase after $8 \mathrm{~h}$. After treatment with EC-G, E. coli growth decreased dramatically in the first $8 \mathrm{~h}$ and retained steadily at approximately $3.45 \times \log _{10} \mathrm{CFU} / \mathrm{mL}$, whereas EC-I treatment decreased the growth in the first $8 \mathrm{~h}$ and retained steadily at approximately $2.99 \times \log _{10} \mathrm{CFU} / \mathrm{mL}$, suggesting a stronger EC-I killing efficacy against $E$. coli.

Similarly, non-treated P. aeruginosa exhibited growth from 5.17 to $8.17 \log _{10} \mathrm{CFU} / \mathrm{mL}$ and moved after $8 \mathrm{~h}$ into the static phase. After treatment with EC-G, P. aeruginosa growth decreased dramatically in the first $4 \mathrm{~h}$ and retained steadily at approximately $2.94 \times \log _{10}$ $\mathrm{CFU} / \mathrm{mL}$. After treatment with EC-I, P. aeruginosa growth decreased in the first $4 \mathrm{~h}$ and was retained steadily at approximately $2.04 \times \log _{10} \mathrm{CFU} / \mathrm{mL}$, suggesting a stronger EC-I killing efficacy against $P$. aeruginosa. The plot of both the samples assessed at the $2 \times$ MIC level was almost similar to that at $1 \times$ MIC. The results indicated that EC-G exhibits a lethal effect on P. aeruginosa and E. coli after $4 \mathrm{~h}$ and $8 \mathrm{~h}$, respectively. 


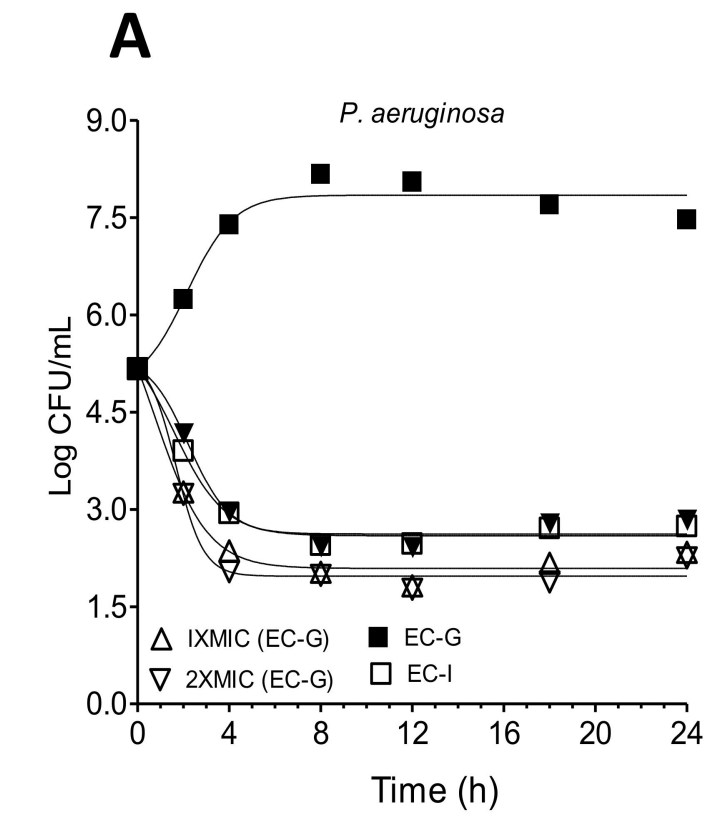

B

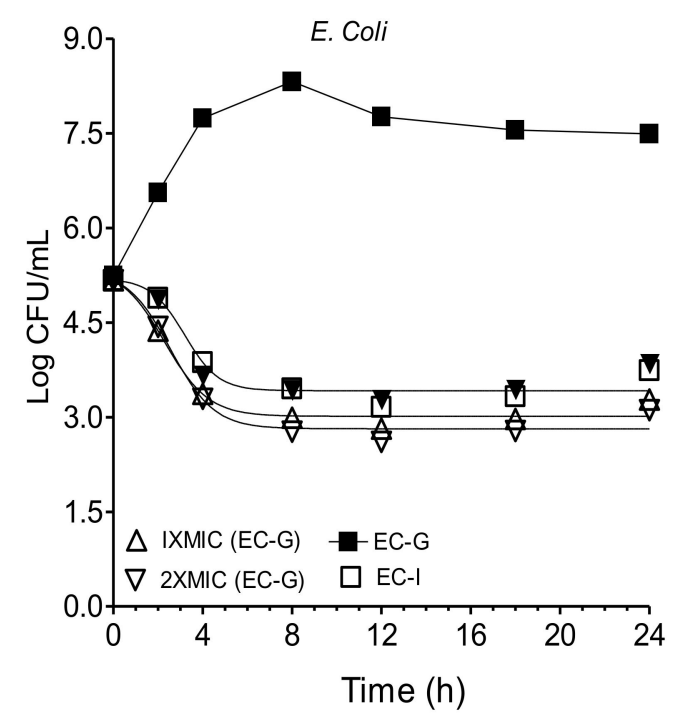

Figure 2. Time-kill analysis of (A) P. aeruginosa and (B) E. coli.

Similarly, EC-I exhibited a lethal effect on the growth of both P. aeruginosa and E. coli after $8 \mathrm{~h}$ of incubation. The plot of both samples measured at the 2-MIC stage was approximately identical to that at 1-MIC. EC-I exhibited a rapid killing effect on P. aeruginosa development, with a lethal effect after $4 \mathrm{~h}$ of incubation and after $8 \mathrm{~h}$ on E. coli. The effects of EC-I on P. aeruginosa and E. coli growth were destroyed after $8 \mathrm{~h}$ of incubation.

\subsection{Gastrointestinal Activity}

\subsubsection{In Vivo Antidiarrheal Study on Mice}

Protection in castor oil-provoked diarrhea: Both orally administered samples of EC-I and EC-G exhibited dose-dependent protection of mice, whereas the saline group did not exhibit any effect. At the lower tested dose of EC.I $(100 \mathrm{mg} / \mathrm{kg})$, two out of five mice exhibited protection, indicating $40 \%$ protection. A higher dose of $200 \mathrm{mg} / \mathrm{kg}$ exhibited $80 \%$ protection, whereas $20 \%$ and $60 \%$ protection was observed at lower $(100 \mathrm{mg} / \mathrm{kg})$ and higher doses $(200 \mathrm{mg} / \mathrm{kg})$, respectively. No diarrheal spot was observed in any mice treated with loperamide (100\% protection) (Table 4$)$.

Table 4. Comparative antidiarrheal activities of the extracted essential oil of Elettaria cardamomum of Indian (EC-I) and Guatemala (EC-G) on castor oil $(10 \mathrm{~mL} / \mathrm{kg})$-induced diarrhea in mice.

\begin{tabular}{ccc}
\hline Treatment $(\mathbf{p . o .})$, Dose $(\mathbf{m g} / \mathbf{k g})$ & No. of Mice with Diarrhea & \% Protection \\
\hline Saline $(10 \mathrm{~mL} / \mathrm{kg})+$ Castor oil & $5 / 5$ & 0 \\
\hline EC-I $(100 \mathrm{mg} / \mathrm{kg})+$ Castor oil & $3 * / 5$ & 40 \\
\hline EC-I $(200 \mathrm{mg} / \mathrm{kg})+$ Castor oil & $1 * / 5$ & 80 \\
\hline EC-G $(100 \mathrm{mg} / \mathrm{kg})+$ Castor oil & $4 / 5$ & 20 \\
\hline EC-G $(200 \mathrm{mg} / \mathrm{kg})+$ Castor oil & $2 * / 5$ & 60 \\
\hline Loperamide $(10 \mathrm{mg} / \mathrm{kg})+$ Castor oil & $0 * * / 5$ & 100 \\
\hline${ }^{*}<0.05$ and $* * p<0.01 \mathrm{vs}$. Saline + Castor oil treated group $\left(\chi^{2}\right.$-test).
\end{tabular}

\subsubsection{Gut Inhibitory Effects}

When tested against $\mathrm{CCh}$ and high $\mathrm{K}^{+}$-mediated spasm in rat ileum preparations, EC-I and EC-G caused dose-dependent $(0.01-5 \mathrm{mg} / \mathrm{mL})$ complete inhibition. In CCh-mediated 
contractions, EC-I exhibited inhibition with resultant $\mathrm{EC}_{50}$ values of $0.76 \mathrm{mg} / \mathrm{mL}[0.54-0.92$, $95 \%$ confidence interval (CI), $n=4]$, whereas EC-G exhibited inhibition with higher $\mathrm{EC}_{50}$ value of $4.22 \mathrm{mg} / \mathrm{mL}(3.86-4.12,95 \% \mathrm{CI}, n=4)$ (Figure 3A). EC-I and EC-G exhibited inhibition against high $\mathrm{K}^{+}$-mediated contractions with $\mathrm{EC}_{50}$ values of $0.08 \mathrm{mg} / \mathrm{mL}(0.06-0.09$, $95 \% \mathrm{CI}, n=4)$ and $0.24 \mathrm{mg} / \mathrm{mL}(0.18-0.28,95 \% \mathrm{CI}, n=4)$, respectively (Figure $3 \mathrm{~B})$.
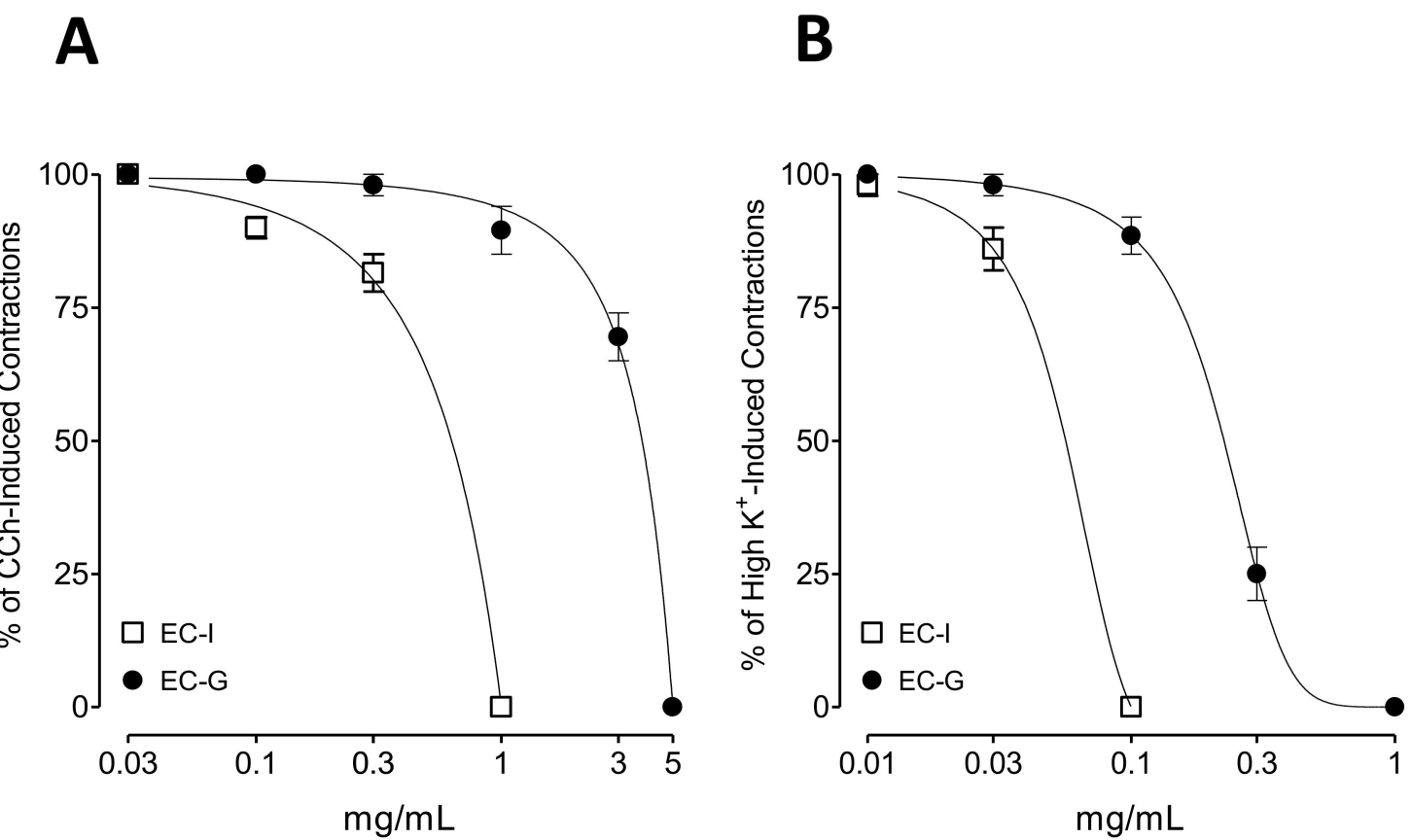

Figure 3. Concentration-response curves showing comparison of the extracted essential oil of Elettaria cardamomum of

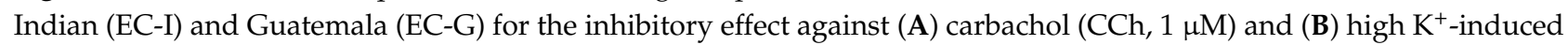
contractions in isolated rat ileum preparations. Values shown are mean $\pm \mathrm{SEM}, n=4$.

\section{Discussion}

Studies have reported that for better fragrances, $\alpha$-terpinyl acetate is always present in higher amount than 1,8 cineole, which may also be an indicator of high-quality $E$. cardamomum essential oils. In the present study, findings of a higher percentage of $\alpha$ terpinyl acetate than 1,8 cineole indicated both samples have good quality essential oil similar to earlier reports [22,23].

In this report, monoterpene components such as $\beta$-phellandrene, $\beta$-pinene, DLlimonene, $\beta$-cis-ocimene, $\gamma$-terpinen, $\alpha$-terpinene, sabinene, $\alpha$-phellandrene, camphene, $\beta$-fenchyl alcohol, terpinen-4-ol, $\alpha$-terpinyl acetate, cis-geranyl acetate, and D-germacrene were observed to be in higher concentrations in the EC-I essential oil. The content of constituents such as $\beta$-trans-ocimene and (+)-2-carene, linalool, Z-citral, trans-geraniol, and (E)-ocimenyl acetate was higher in the EC-G essential oil. These components have also been reported by several investigators [24-26]. Trans-sabinenhydrate was the major oxygenated monoterpenes identified only in the EC-I sample, whereas thymol, $\alpha$-phellandren-8-ol, (D)-verbenone, and dihydrocarveol were other major oxygenated monoterpene identified only in EC-G.

The concentration of sesquiterpene D-germacrene was higher in the essential oils of EC-I, whereas $\beta$-elemene, $\alpha$-murolene, bicyclo[5.2.0]nonane, 2-methylene-4,8,8-trimethyl-4-vinyl-, $\delta$-guaiene, $\gamma$-gurjunene, D-germacrene, $D$-nerolidol, $(Z, Z)$-farnesal, trans-caryophyllene oxide, aromadendrene oxide-(1), and farnesyl acetate were in higher concentrations in the essential oil of EC-G capsules. Sesquiterpenes such as $\alpha$-selinene, $\alpha$-caryophyllene, and $(Z, E)$ farnesal were identified only in the essential oil of EC-I, whereas ledene, alloaromadendrene, $\alpha$-cadinol, $\gamma$-eudesmol, 10-epi, $\beta$-spathulenol, longifolenaldehyde, costunolide, 
and isoaromadendrene epoxide were identified only in EC-G. Diterpene and $\alpha$-springene were observed in both the samples $(0.43 \%$ and $1.08 \%$ in EC-G and EC-I oils, respectively), whereas cembrene, kauran-18-al, 17-(acetyloxy)-, (4.beta), and thunbergol were found only in the essential oil of EC-G. Some of these components have not been previously reported in the GC-MS analysis of cardamom essential oil.

In the current study, monoterpenes were in higher concentrations in EC-I (83.24\%) than in EC-G (73.03\%), whereas sesquiterpenes were in higher concentrations in EC-G $(18.35 \%)$ than in EC-I (9.27\%). However, no significant differences in diterpenes $(1.03 \%$ and $1.08 \%$ in the EC-G and EC-I, respectively) were reported between EC-I and EC-G. Gradinaru et al. reported $84.54 \%$ oxygenated monoterpenes and $8.27 \%$ monoterpene hydrocarbons [27], whereas Kumar et al. reported approximately $87 \%$ oxygenated monoterpenes and $8.24 \%$ monoterpene hydrocarbons in the essential oil of different cardamom samples [28]. Noumi et al. reported the presence of approximately $88.7 \%$ oxygenated monoterpenes and $7 \%$ monoterpene hydrocarbons in cardamom essential oils [26].

In the present investigation, two Gram-negative bacterial strains, P. aeruginosa and $E$. coli, were chosen for measuring the antibacterial activity as these bacteria are becoming resistant to various drugs, and scientists are exploring new molecules to combat these resistant strains. In this study, both samples exhibited antibacterial effects against both selected Gram-negative bacteria, where the MIC of EC-I was lower than that of EC-G oil. In the current study, we obtained 10.13 and $14.4 \mathrm{~mm}$ zone of inhibition and MIC $1 \mathrm{mg} / \mathrm{mL}$ and $0.5 \mathrm{mg} / \mathrm{mL}$ against E. coli for EC-G and EC-I respectively. Similarly, we obtained 12.33 and $16.66 \mathrm{~mm}$ zone of inhibition and MIC $0.5 \mathrm{mg} / \mathrm{mL}$ and $0.25 \mathrm{mg} / \mathrm{mL}$ against $P$. aeruginosa for EC-G and EC-I respectively, which indicates that the tested oils are effective. In a previous study, Noumi et al., (2018) reported the range of MIC of E. coli $(0.048-0.097 \mathrm{mg} / \mathrm{mL})$ and $P$. aeruginosa $(0.048 \mathrm{mg} / \mathrm{mL})$ for the green cardamom essential oil, which supports the present antimicrobial activity [26]. Although we tested the zone of inhibition for gentamycin against $P$. aeruginosa and E. coli (22.7 $\mathrm{mm}$ and $19.67 \mathrm{~mm}$, respectively), we could not test the MIC due to certain limitations. Similar zones of inhibition for gentamycin have also been reported in previous studies [29,30]. Compared to the MIC of gentamycin from literature, i.e., less than $0.00156 \mathrm{mg} / \mathrm{mL}$ and $0.00313 \mathrm{mg} / \mathrm{mL}$ against $E$. coli and P. aeruginosa, respectively [31], we get another interpretation, which is that the antibacterial activity is present, but compared to the positive control, it seems marginal. This, however, is not surprising as an extract is the mixture of compounds with different chemical constituents amongst whom some may and some may not have antibacterial activities. Hence, isolation of these compounds would be the ideal method to predict whether or not the antibacterial activity is at an appreciable extent or not. Thus, for adding further validity, we will direct our future studies to not only assess the effect of cardamom oil on different pathogenic bacteria involved in gastrointestinal diseases but we will also test the different compounds isolated and subsequently compare them with respective controls including vancomycin and gentamycin for Gram-positive and Gram-negative microbes respectively.

The major compounds $\alpha$-terpinyl acetate $(24.65 \%)$ and 1,8 -Cineole $(14.03 \%)$ were identified higher in EC-I than EC-G (18.71\% and 10.59\% respectively). The high antibacterial effects of EC-I are mainly due to these compounds and the other compounds that have antibacterial effects. The compound $\alpha$-terpinyl acetate is nontoxic and has an effect on neurological disease with anti-inflammatory and anticancer effects [32], similarly, 1,8-Cineole has also been reported as nontoxic [33].

The monoterpene hydrocarbons and oxygenated monoterpenes in the essential oil of different plants possess major antimicrobial, antifungal, and antiviral activities [34]. Our results indicating antibacterial activity against $E$. coli and P. aeruginosa are concurrent with those of other studies $[20,21]$. The cardamom oil was probably active against $P$. aeruginosa and $E$. coli due to the presence of 1,8 cineole and $\alpha$-terpinyl acetate, which is supported by several investigations [13,34]. Time-kill kinetic studies indicated that essential oil of $E$. cardamomum exhibits bacteriostatic activities against P. aeruginosa and E. coli, which may be 
due to the presence of 1,8 cineole, $\alpha$-terpinyl acetate, and other active antimicrobial volatile agents [35-37].

Keeping in view the medicinal use of E. cardamomum in multiple gut-related disorders, the essential oils of EC-I (India) and EC-G (Guatemala) were evaluated and compared for their antidiarrheal and gut inhibitory activities through in vivo and in vitro assays. A castor oil-induced diarrhea model was used to study the antidiarrheal effect, whereas isolated rat ileum preparations were used in the in vitro experiments for elucidation of the detailed mechanism [38]. Diarrhea was induced in normal mice by using castor oil, which after hydrolysis into ricinoleic acid, led to evoked spasms in the gut [39]. Pre-administration of both $E C-I$ and $E C-G$ protected the mice from diarrhea in a dose-dependent manner; however, higher potency was observed with EC-I. After observing the antidiarrheal response, the method described by Palla et al. was followed to test and compare both the samples for antispasmodic effect in vitro in the isolated rat ileum [40]. For this purpose, EC-I and EC-G cumulative concentrations were added to organ bath after inducing sustained contractions with $\mathrm{CCh}$ and high $\mathrm{K}^{+}$. Interestingly, both samples demonstrated a dose-dependent complete inhibition of both types of contraction. A critical analysis of the pattern of the inhibitory CRCs of $E C-I$ and $E C-G$ against $C C h$ and high $\mathrm{K}^{+}$-induced contractions indicated that $E C-I$ produces relaxation with significantly higher $(p<0.05)$ potency than $E C-G$. The mechanism supposed to be involved in the antispasmodic effect might be the inhibition of a phosphodiesterase (PDE) enzyme [12] and voltage-dependent $\mathrm{Ca}^{++}$channels, because both these mechanisms are involved in smooth muscles relaxation $[41,42]$. The antidiarrheal effect of EC-I is related to the inhibition of smooth muscle contraction and may be due to the presence of high concentration of the major compound $\alpha$-terpinyl acetate and 1,8 cineole in this essential oil [43]. The present study elucidates an additional antispasmodic mechanism of cardamom not reported so far, namely the PDE enzyme inhibition. Gilani et al. reported $\mathrm{Ca}^{++}$channel blocking-like mechanisms; however, they did not test it against CCh-induced contractions, which are used to decipher the PDE inhibitory and/or cholinergic mechanisms (REF). Gilani et al. used aqueous methanolic extract, whereas we used essential oil of cardamom [12]. However, our results are also concurrent with those reported by Gilani et al., because they reported that the petroleum ether fraction of cardamom is the most potent in the CCB activity (inhibitory effect at $0.1 \mathrm{mg} / \mathrm{mL}$ ). We explored the antispasmodic and antidiarrheal effects of cardamom essential oils for the first time, and our findings indicate that the activity of oils varies mainly due to the presence of 1,8 cineole [44]. Compound $\alpha$-terpinyl acetate inhibited cytochrome P450 enzyme [45]; inhibition of this enzyme may contribute to antidiarrheal effects [46]. In several studies, plants containing major compounds such as sesquiterpenes have also been reported for the biological effects including antimicrobials and antidiarrheal [43,47], so not only the monoterpenes but sesquiterpenes may also contribute to the antidiarrheal effects.

One of the limitations of the current study is that we did not use positive control in our antibacterial assay. For adding further validity, we will direct our future studies to assess the effect of cardamom oil on different pathogenic bacteria involved in gastrointestinal diseases along with using the respective controls including vancomycin and gentamycin for Gram-positive and Gram-negative microbes respectively.

\section{Materials and Methods}

\subsection{Fruits Samples and Chemicals}

Capsules of Indian green cardamom (EC-I) (Emperor Akbar; $250 \mathrm{~g}$ ) and Guatemalan green cardamom (EC-G) (Al-Othaim; $1 \mathrm{~kg}$ ) were purchased in January 2019 from the Al-Kharj, Saudi Arabia. Samples were authenticated and kept in the herbarium (Indian: EC-Indian-01-PSAU/3/20 and Guatemala: EC-Guatemala-PSAU/2/20) of the Department of Pharmacognosy, College of Pharmacy, Prince Sattam Bin Abdulaziz University, Al-Kharj, Saudi Arabia. Carbamylcholine (CCh), loperamide, and acetylcholine perchlorate (ACh) were obtained from Sigma Company, St. Louis, MO, USA. Potassium chloride (Sigma Co), calcium chloride, glucose, magnesium sulphate, potassium dihydrogen phosphate, sodium 
bicarbonate, and sodium chloride (Merck, Darmstadt, Germany) were used as reagents (salts) to prepare physiological buffer solution (Tyrode). All chemicals were of analytical grade, whereas castor oil was purchased from a local pharmacy.

\subsection{Isolation of Essential Oils}

The capsules were ground, and the essential oil was extracted using a Clevenger apparatus. For $3 \mathrm{~h}, 100 \mathrm{~g}$ of each sample powder was extracted, and the percentage yield was calculated after repeating the process thrice. The extracted essential oils were dried over anhydrous $\mathrm{Na}_{2} \mathrm{SO}_{4}$, transferred to an amber-coloured tight vial, labelled as EC-I or EC-G, and stored at $4{ }^{\circ} \mathrm{C}$ for further analysis.

\subsection{Gas Chromatography-Mass Spectrometry Analysis}

The gas chromatography-mass spectrometry (GC-MS) analysis of EC-I and EC-G essential oils was performed using the Shimadzu GC-MS system (TQ-8040, Tokyo, Japan) equipped with auto-sampler (AOC-20i). Analysis of the chemical composition was performed in the ionization mode $(70 \mathrm{eV})$ with a scan time of $0.3 \mathrm{~s}$ and $m / z$ range of $45-400 \mathrm{u}$. Both the injector and detector temperatures were set at $210{ }^{\circ} \mathrm{C}$. The Rxi-5 MS capillary column $(0.25 \mathrm{~mm}$ inner diameter, $30 \mathrm{~m} \times 0.25 \mu \mathrm{m})$ contained the stationary phase comprising 5\% two-phenyl and $95 \%$ two-methyl polysiloxane. The column temperature was programmed as follows: Initial oven temperature programmed at $40^{\circ} \mathrm{C}$, held for 3 min; gradually raised to $90^{\circ} \mathrm{C}$ at $3{ }^{\circ} \mathrm{C} / \mathrm{min}$, held for $4 \mathrm{~min}$; raised to $115^{\circ} \mathrm{C}$ at $3{ }^{\circ} \mathrm{C} / \mathrm{min}$, held for $10 \mathrm{~min}$; and then increased to $140^{\circ} \mathrm{C}$ at $2{ }^{\circ} \mathrm{C} / \mathrm{min}$ and held for $8 \mathrm{~min}$. Finally, the column temperature was increased to $210^{\circ} \mathrm{C}$ at $3{ }^{\circ} \mathrm{C} / \mathrm{min}$ and held for $5 \mathrm{~min}$. The carrier gas was helium $(99.995 \%)$ at a constant flow rate of $1 \mathrm{~mL} / \mathrm{min}$. The oil identification composition was based on a comparison of their mass spectra and retention time with data of libraries, NIST-14 and NIST-14s (National Institute of Standards and Technologies, Mass Spectra Libraries, Gaithersburg, Maryland, USA) [48].

\subsection{Antibacterial Activity}

The antibacterial effect of the EC-I and EC-G oils was tested against two bacterial strains, namely P. aeruginosa (ATCC 27853) and E. coli (ATCC 35218). The antibacterial activity of the essential oils was assayed using the disc diffusion method [49] with some modification, and each test was repeated thrice. Mueller-Hinton agar (MHA) was used for the antibacterial assay. P. aeruginosa and E. coli cultures in nutrient broth (HiMedia labs, Mumbai, India) were separately inoculated and grown for $18 \mathrm{~h}$ at $37^{\circ} \mathrm{C}$. The suspension of both the organisms was separately diluted with saline (phosphate buffer, $\mathrm{pH}$ 7.4) to obtain $1 \times 10^{6}$ colony forming units $(\mathrm{CFU} / \mathrm{mL})$ of microbial suspension.

The bacterial inocula were streaked onto an MHA plate by using a sterile swab. A 6-mm sterile disk was impregnated with $10 \mu \mathrm{L}$ of $5 \mathrm{mg} / \mathrm{mL}$ EC-I and EC-G essential oil prepared in $2 \%$ DMSO, and $2 \%$ dimethyl sulfoxide (DMSO) was used as the negative control. The plates were labelled, and the disks containing essential oil were placed onto the plates and incubated for $18-24 \mathrm{~h}$ at $37^{\circ} \mathrm{C}$. The diameter of inhibition around the disk was measured and the mean of three tests was reported as the zone of inhibition. Gentamicin $(10 \mu \mathrm{g})$ was used as a positive control.

Different concentrations $(4,2,1,0.5,0.25$, and $0.125 \mathrm{mg} / \mathrm{mL})$ of EC-I and EC-G essential oil were prepared in analytical grade $2 \%$ DMSO and used for the determination of minimum inhibitory concentration (MIC) through the broth dilution method according to methods described by CLSI 2006 [50]. To each diluted tube, $100 \mu \mathrm{L}$ inoculum was seeded and the control tubes (no bacterial inoculation) were simultaneously maintained. All tubes were incubated at $37^{\circ} \mathrm{C}$ for $24 \mathrm{~h}$ and the lowest concentration of the essential oils that produced no visible bacterial growth was recorded. 


\subsection{Time-Kill Analysis}

Time-kill kinetics of essential oil of EC-G and EC-I samples was performed using the method described by Kang et al. [51] with slight modification. Two concentrations equivalent to $1 \times$ MIC $(1 \mathrm{mg} / \mathrm{mL}$ and $0.5 \mathrm{mg} / \mathrm{mL}$ for $E$. coli and P. aeruginosa, respectively) and $2 \times$ MIC $(2 \mathrm{mg} / \mathrm{mL}$ and $1 \mathrm{mg} / \mathrm{mL}$ for E. coli and P. aeruginosa, respectively) of the essential oil were prepared. An inoculum size of $1 \times 10^{6} \mathrm{CFU} / \mathrm{mL}$ was added and incubated at $37^{\circ} \mathrm{C}$. A total of 1-mm inoculum of the medium was obtained at different time intervals of $0,2,4,8,12,18$, and $24 \mathrm{~h}$. The colony forming unit (CFU) of the bacterial cells was determined. A negative control containing organisms and DMSO (without essential oil) was also evaluated. The assays were performed in triplicate, and time-kill graphs were constructed by calculating the $\log \mathrm{CFU} / \mathrm{mL}$ of mean colony count against time.

\subsection{Experimental Animals}

Animals: Wistar rats (200-250 g; 6-8 weeks old) and Swiss albino mice (25-30 g; 12 weeks or more) of either sex were purchased from the local animal vendors and housed in the animal house of the Barrett Hodgson University (BHU), Karachi, Pakistan. The animals were placed in the transparent plastic rectangular cages $\left(47 \times 34 \times 18 \mathrm{~cm}^{3}\right)$ whose bedding (sawdust) was refreshed every $48 \mathrm{~h}$. Standard temperature $\left(23-25^{\circ} \mathrm{C}\right)$ and a light:dark (12:12) cycle were maintained. During housing, the health status of the animals was also monitored. Standard animal diet was fed, which comprised of flour $(380 \mathrm{~g} / \mathrm{kg})$, fish meal $(170 \mathrm{~g} / \mathrm{kg})$, fiber $(380 \mathrm{~g} / \mathrm{kg})$, molasses $(12 \mathrm{~g} / \mathrm{kg}), \mathrm{NaCl}(5.8 \mathrm{~g} / \mathrm{kg})$, nutrivet L. $(2.5 \mathrm{~g} / \mathrm{kg})$, potassium metabisulfate $(1.2 \mathrm{~g} / \mathrm{kg})$, powdered milk $(150 \mathrm{~g} / \mathrm{kg})$ and vegetable oil $(38 \mathrm{~g} / \mathrm{kg})$, whereas they were provided with water ad libitum. Before the commencement of the experiments, animals were fasted for a day before the experiment $(24 \mathrm{~h})$, however, they were provided with a supply of water. The rats were sacrificed under light anesthesia (using thiopental sodium 70-90 mg/kg; i.p.), followed by cervical dislocation. The guidelines detailed in the National Research Council [52] were followed for all animal-based experiments. The protocols were approved by the Ethical Committee of Research on Animals of the BHU bearing ERC number: BHU-ERC/Pharmacy-001/2020/PIDr. Amber Hanif Palla. All results were reported in accordance with the Animal Research: Report of In-vivo Experiments (ARRIVE) guidelines [53].

\subsection{Gastrointestinal Activities}

\subsubsection{In Vivo Antidiarrheal Study on Mice}

A total of 35 mice were arbitrarily allocated to seven groups with equal numbers of mice in each group. Following $24 \mathrm{~h}$ of fasting, mice of the first and second groups were exposed to oral gavage of saline $(10 \mathrm{~mL} / \mathrm{kg})$ and labelled as sham control and negative control, respectively. After pilot screening for dose selection, the third and fourth groups (test groups) were administered two increasing doses of EC-I (100 and $200 \mathrm{mg} / \mathrm{kg}$; P.O), whereas the fifth and sixth groups were administered EC-G (100 and $200 \mathrm{mg} / \mathrm{kg}$ ). The last group was administered loperamide $(10 \mathrm{mg} / \mathrm{kg}$, P.O.) and labelled as the positive control. Separate cages were assigned to each animal with a blotting sheet on the floor of each cage to know the absence or presence of diarrhea by a blinded observer. After $1 \mathrm{~h}$, all mice except the sham controls were orally exposed to castor oil $(10 \mathrm{~mL} / \mathrm{kg})$ by using a 1-mL syringe. After $4 \mathrm{~h}$, blotting sheets in all individual cages were inspected for typical diarrheal droppings. Protection was noted in the case of diarrheal drops, as previously reported by Rehman et al., [54].

\subsubsection{In Vitro Antispasmodic Activity on Isolated Rat Ileum}

The method described by Shah et al., [55] was followed to sacrifice rats and to isolate the ileum, the last part of the small intestine. Briefly, rats were anaesthetized with thiopental sodium $(70 \mathrm{mg} / \mathrm{kg}$, given intraperitoneally) and then cervically dislocated by a blow on the head. Following isolation, required segments of the ileum $(2-3 \mathrm{~cm}$ length) were cleaned from adjacent tissues and fecal material and mounted in a tissue bath (volume $20 \mathrm{~mL}$ ) 
that was attached with an isotonic transducer coupled to a digital PowerLab (ML-845) data acquisition system (AD Instruments; Sydney, Australia) and a computer using lab chart software (Version 5.3). A fresh tyrode was filled in 20-mL tissue baths gassed with carbogen, and temperature was set at $37^{\circ} \mathrm{C}$. The composition of Tyrode's solution (mM) was as follows: $\mathrm{KCl}, 2.68 ; \mathrm{NaCl}, 136.9 ; \mathrm{MgCl}_{2}, 1.05 ; \mathrm{NaHCO}_{3}, 11.90 ; \mathrm{NaH}_{2} \mathrm{PO}_{4}, 0.42 ; \mathrm{CaCl}_{2}$, 1.8; and glucose, 5.55; $\mathrm{pH} 7.4$. Tension of $1 \mathrm{~g}$ was applied by rotating the transducer knob clockwise, and the tissues were left for stabilisation for $30 \mathrm{~min}$ with multiple exposures to acetylcholine $(0.3 \mu \mathrm{M})$. After obtaining the stable band in the spontaneous ileal contractions, test samples were added to the bath solution in increasing concentrations, which resulted in the inhibition of the $\mathrm{CCh}$ and high $\mathrm{K}^{+}$-induced contractions.

\subsection{Statistics}

Results of the antibacterial assay were expressed as the mean of three repeated experiments. Protection from diarrhea was statistically evaluated by comparing all the groups with the saline control group by using Chi square $\left(\chi^{2}\right)$ test. A $p$ value of $<0.05$ was considered statistically significant. Results of the antispasmodic activity assay are expressed as mean \pm standard error of mean (SEM). The statistical parameters applied were Student's $t$-test or two-way ANOVA followed by Bonferroni's post-test for multiple comparisons of concentration-response curves (CRCs) with control. Graph Pad prism (version 4) was used for regression analysis of CRCs.

\section{Conclusions}

The present findings of GC-MS analysis revealed that $\alpha$-terpinyl acetate and 1,8 cineole are the major components comparatively higher in EC-I. Monoterpenes were identified as the major components in both the essential oils; however, EC-I was showed to have a higher percentage of monoterpenes than EC-G. Both EC-G and EC-I oils possessed significant antibacterial activity, with EC-I processing more active components than EC-G essential oils. In addition to the antibacterial activity, essential oil of E. cardamomum also exhibited antidiarrheal effects along with the antispasmodic activity. Overall, these differences may be due to the presence of different percentages of active and other constituents in the EC-G and EC-I samples. Thus, EC-I exerts more potent antidiarrheal and antispasmodic effects than EC-G. Therefore, present finding delivers a scientific support for the possible future use of E. cardamomum essential oil as an antidiarrheal agent.

Author Contributions: Conceptualization, A.A. and N.U.R.; methodology, A.A., N.U.R., M.N.A. and A.H.P.; formal analysis, A.A. and A.H.P.; investigation, A.A., N.U.R., M.N.A. and A.H.P.; resources, A.A. and N.U.R.; data curation, N.U.R., M.N.A. and A.A.; writing-original draft preparation, A.A. and N.U.R.; writing-review and editing, M.N.A. and A.H.P.; visualization, A.A. and N.U.R.; supervision, A.A.; project administration, A.A.; funding acquisition, A.A., N.U.R. and M.N.A. All authors have read and agreed to the published version of the manuscript.

Funding: This study received no external funding.

Institutional Review Board Statement: The protocols were approved by the Ethical Committee of Research on Animals of the BHU bearing ERC number: BHU-ERC/Pharmacy-001/2020/PI-Dr. Amber Hanif Palla.

Informed Consent Statement: Not applicable.

Data Availability Statement: Data supporting the findings of this study are available within the article.

Conflicts of Interest: The authors declare no conflict of interest.

Sample Availability: Fruits samples are available at Department of Pharmacognosy, College of Pharmacy, PSAU-Al-Kharj, KSA. 


\section{References}

1. Cyriac, A.; Paul, R.; Anupama, K.; Senthil Kumar, R.; Sheeja, T.E.; Nirmal Babu, K.; Parthasarathy, V.A. Isolation and characterization of genomic microsatellite markers for small cardamom (Elettaria cardamomum Maton) for utility in genetic diversity analysis. Physiol. Mol. Biol. Plants 2016, 22, 219-229. [CrossRef] [PubMed]

2. Cyriac, A.; Aghasi, M.; Ghazi-Zahedi, S.; Koohdani, F.; Siassi, F.; Nasli-Esfahani, E.; Keshavarz, A.; Qorbani, M.; Khoshamal, H.; Salari-Moghaddam, A.; et al. The effects of green cardamom supplementation on blood glucose, lipids profile, oxidative stress, sirtuin- 1 and irisin in type 2 diabetic patients: A study protocol for a randomized placebo-controlled clinical trial. BMC Complement Altern. Med. 2018, 18, 18.

3. Man, A.; Santacroce, L.; Jacob, R.; Mare, A.; Man, L. Antimicrobial Activity of Six Essential Oils Against a Group of Human Pathogens: A Comparative Study. Pathogens 2019, 8, 15.

4. Figueiredo, A.C.; Barroso, J.G.; Pedro, L.G.; Scheffer, J.J. Factors affecting secondary metabolite production in plants: Volatile components and essential oils. Flavour. Fragr. J. 2008, 23, 213-226. [CrossRef]

5. Ashokkumar, K.; Murugan, M.; Dhanya, M.K.; Warkentin, T.D. Botany, traditional uses, phytochemistry and biological activities of cardamom [Elettaria cardamomum (L.) Maton]_A critical review. J. Ethnopharmacol. 2020, 246, 112244. [CrossRef] [PubMed]

6. EFSA. (European Food Safety Authority). Safety and efficacy of an essential oil from Elettaria cardamomum (L.) Maton when used as a sensory additive in feed for all animal species. EFSA J. 2019, 17, e05721.

7. Swamy, M.K.; Akhtar, M.S.; Sinniah, U.R. Antimicrobial Properties of Plant Essential Oils against Human Pathogens and Their Mode of Action: An Updated Review. Evid. Based Complement Altern. Med. 2016, 2016, 3012462. [CrossRef]

8. Sarkic, A.; Stappen, I. Essential Oils and Their Single Compounds in Cosmetics-A Critical Review. Cosmetics 2018, 5, 11. [CrossRef]

9. Helal, I.M.; El-Bessoumy, A.; Al-Bataineh, E.; Joseph, M.R.P.; Rajagopalan, P.; Chandramoorthy, H.C.; Ahmed, S.B.H. Antimicrobial Efficiency of Essential Oils from Traditional Medicinal Plants of Asir Region, Saudi Arabia, over Drug Resistant Isolates. BioMed. Res. Int. 2019, 2019, 8928306. [CrossRef]

10. Singh, R.; Kaushik, R.; Jaglan, V. Antibacterial and antioxidant activity of green cardamom and rosemary extract in food products: A brief review. Pharma Innov. J. 2018, 7, 568-573.

11. Al-Zuhair, H.; el-Sayeh, B.; Ameen, H.A.; al-Shoora, H. Pharmacological studies of cardamom oil in animals. Pharmacol. Res. 1996, 34, 79-82. [CrossRef] [PubMed]

12. Gilani, A.H.; Jabeen, Q.; Khan, A.U.; Shah, A.J. Gut modulatory, blood pressure lowering, diuretic and sedative activities of cardamom. J. Ethnopharmacol. 2008, 115, 463-472. [CrossRef] [PubMed]

13. Snoussi, M.; Noumi, E.; Dehmani, A.; Flamini, G.; Aouni, M.; Al-sieni, M.; Al-sieni, A. Chemical Composition and Antimicrobial Activities of Elettaria cardamomum L. (Manton) Essential Oil: A High Activity against a Wide Range of Food Borne and Medically Important Bacteria and Fungi. J. Chem. Biol. Phys. Sci. 2015, 6, 248-259.

14. Singh, G.; Kiran, S.; Marimuthu, P.; Isidorov, V.; Vinogorova, V. Antioxidant and antimicrobial activities of essential oil and various oleoresins of Elettaria cardamomum (seeds and pods). J. Sci. Food Agric. 2008, 88, 280-289. [CrossRef]

15. Boxall, M.D.; Day, M.R.; Greig, D.R.; Jenkins, C. Antimicrobial resistance profiles of diarrheagenic Escherichia coli isolated from travellers returning to the UK, 2015-2017. J. Med. Microbiol. 2020, 69, 932-943. [CrossRef] [PubMed]

16. Chuang, C.H.; Janapatla, R.P.; Wang, Y.H.; Chang, H.J.; Huang, Y.C.; Lin, T.Y.; Chiu, C.H. Pseudomonas aeruginosa-associated Diarrheal Diseases in Children. Pediatr. Infect Dis. J. 2017, 36, 1119-1123. [CrossRef]

17. Hoff, R.T.; Patel, A.; Shapiro, A. Pseudomonas aeruginosa: An Uncommon Cause of Antibiotic-Associated Diarrhea in an Immunocompetent Ambulatory Adult. Case Rep. Gastrointest Med. 2020, 2020, 61748.

18. Pachori, P.; Gothalwal, R.; Gandhi, P. Emergence of antibiotic resistance Pseudomonas aeruginosa in intensive care unit; a critical review. Genes Dis. 2019, 6, 109-119. [CrossRef]

19. Fakhkhari, P.; Tajeddin, E.; Azimirad, M.; Salmanzadeh-Ahrabi, S.; Abdi-Ali, A.; Nikmanesh, B.; Eshrati, B.; Gouya, M.M.; Owlia, P.; Zali, M.R.; et al. Involvement of Pseudomonas aeruginosa in the occurrence of community and hospital acquired diarrhea, and its virulence diversity among the stool and the environmental samples. Int. J. Environ. Health Res. 2020, 19, 1-11. [CrossRef]

20. Agaoglu, S.; Dostbil, N.; Alemdar, S. Antimicrobial activity of some spices used in the meat industry. Bull. Vet. Inst. Pulawy 2007, $51,53-57$.

21. Ahmed, H.M.; Ramadhani, A.M.; Erwa, I.Y. Phytochemical screening, chemical composition and antibacterial activity of essential oil of cardamom. World J. Pharm. Res. 2019, 8, 1166-1175.

22. Asghar, A.; Butt, M.S.; Shahid, M.; Huang, Q. Evaluating the antimicrobial potential of green cardamom essential oil focusing on quorum sensing inhibition of Chromobacterium violaceum. J. Food Sci. Technol. 2017, 54, 2306-2315. [CrossRef] [PubMed]

23. Alam, A.; Majumdar, R.S.; Alam, P. Systematics Evaluations of Morphological Traits, Chemical Composition, and Antimicrobial Properties of Selected Varieties of Elettaria cardamomum (L.) Maton. Nat. Prod. Commun. 2019, 14, 1-7.

24. Savan, E.K.; Kucukbay, F.Z. Essential oil composition of Elettaria cardamomum Maton. J. Appl. Biol. Sci. $2013,7,42-44$.

25. Mutlu-Ingok, A.; Karbancioglu-Guler, F. Cardamom, cumin, and dill weed essential oils: Chemical compositions, antimicrobial activities, and mechanisms of action against Campylobacter spp. Molecules 2017, 22, 1191. [CrossRef]

26. Noumi, E.; Snoussim, M.; Alreshidi, M.M.; Rekha, P.D.; Saptami, K.; Caputo, L.; De Martino, L.; Souza, L.F.; Msaada, K.; Mancini, E.; et al. Chemical and Biological Evaluation of Essential Oils from Cardamom Species. Molecules 2018, 23, 2818. [CrossRef] 
27. Gradinaru, A.C.; Aprotosoaie, A.C.; Trifan, A.; Spac, A.; Brebu, M.; Miron, A. Interactions between cardamom essential oil and conventional antibiotics against Staphylococcus aureus clinical isolates. Farmacia 2014, 62, 1214-1222.

28. Kumar, A.; Tandon, S.; Ahmad, J.; Yadav, A.; Kahol, A.P. Essential oil composition of seed and fruit Coat of Elettaria cardamomum from South India. J. Essent Oil-Bear Plants 2005, 8, 204-207. [CrossRef]

29. Cheruiyot, K.R.; Olila, D.; Kateregga, J. In-vitro antibacterial activity of selected medicinal plants from Longisa region of Bomet district, Kenya. Afr. Health Sci. 2009, 9, S42-S46.

30. Padhi, L.; Panda, S.K. Antibacterial activity of Eleutherine bulbosa against multidrug-resistant bacteria. J. Acute Med. 2015, 5, 53-61. [CrossRef]

31. Lee, W.X.; Basri, D.F.; Ghazali, A.R. Bactericidal Effect of Pterostilbene Alone and in Combination with Gentamicin against Human Pathogenic Bacteria. Molecules 2017, 22, 463. [CrossRef]

32. Chowdhury, S.; Kumar, S. Alpha-terpinyl acetate: A natural monoterpenoid from Elettaria cardamomum as multi-target directed ligand in Alzheimer's disease. J. Funct. Food 2020, 68, 103892. [CrossRef]

33. Xu, J.; Hu, Z.Q.; Wang, C.; Yin, Z.Q.; Wei, Q.; Zhou, L.J.; Li, L.; Du, Y.H.; Jia, R.Y.; Li, M.; et al. Acute and subacute toxicity study of 1,8-cineole in mice. Int. J. Clin. Exp. Pathol. 2014, 7, 1495-1501. [PubMed]

34. Nazzaro, F.; Fratianni, F.; De Martino, L.; Coppola, R.; De Feo, V. Effect of essential oils on pathogenic bacteria. Pharmaceuticals 2013, 6, 1451-1474. [CrossRef] [PubMed]

35. Li, L.; Li, Z.W.; Yin, Z.Q.; Wei, Q.; Jia, R.Y.; Zhou, L.J.; Xu, J.; Song, X.; Zhou, Y.; Du, Y.H.; et al. Antibacterial activity of leaf essential oil and its constituents from Cinnamomum longepaniculatum. Int. J. Clin. Exp. Med. 2014, 7, 1721-1727.

36. Şimşek, M.; Duman, R. Investigation of Effect of 1,8-cineole on Antimicrobial Activity of Chlorhexidine Gluconate. Pharmacogn. Res. 2017, 9, 234-237. [CrossRef]

37. Ghaffari, T.; Kafil, H.S.; Asnaashari, S.; Farajnia, S.; Delazar, A.; Baek, S.C.; Hamishehkar, H.; Kim, K.H. Chemical Composition and Antimicrobial Activity of Essential Oils from the Aerial Parts of Pinus eldarica Grown in Northwestern Iran. Molecules 2019, 24, 3203. [CrossRef] [PubMed]

38. Iwao, I.; Terada, Y. On the mechanism of diarrhea due to castor oil. Jpn. J. Pharmacol. 1962, 12, 137-145. [CrossRef]

39. Croci, T.; Landi, M.; Elmonds-Alt, X.; Le-Fur, G.; Maffrand, J.P.; Manara, L. Role of tachykinins in castor oil-induced diarrhea in rats. Br. J. Pharmacol. 1997, 121, 375-380. [CrossRef] [PubMed]

40. Palla, A.; Gilani, A.H.; Bashir, S.; Rehman, N.U. Multiple mechanisms of Flaxseed-effectiveness in Inflammatory Bowel disease. Evid-Based Complementary Altern. Med. 2020, 2020, 7974835. [CrossRef]

41. Hamilton, T.C.; Weir, S.W.; Weston, T.H. Comparison of the effects of BRL34915 and verapamil on electrical and mechanical activity in rat portal vein. Br. J. Pharmacol. 1986, 88, 103-111. [CrossRef] [PubMed]

42. Kaneda, T.; Takeuchi, Y.; Matsui, H.; Shimizu, K.; Urakawa, N.; Nakajyo, S. Inhibitory mechanism of papaverine on carbacholinduced contraction in bovine trachea. J. Pharmacol. Sci. 2005, 98, 275-282. [CrossRef] [PubMed]

43. Heghes, S.C.; Vostinaru, O.; Rus, L.M.; Cristina Mogosan, C.; Iuga, C.A. Filip L Antispasmodic Effect of Essential Oils and Their Constituents: A Review. Molecules 2019, 24, 1675. [CrossRef] [PubMed]

44. Jalilzadeh-Amin, G.; Maham, M. The application of 1,8-cineole, a terpenoid oxide present in medicinal plants, inhibits castor oil-induced diarrhea in rats. Pharm. Biol. 2015, 53, 594-599. [CrossRef] [PubMed]

45. Lee, Y.; Park, H.G.; Kim, V.; Cho, M.A.; Kim, H.; Ho, T.H.; Cho, K.S.; Lee, I.S.; Kim, D. Inhibitory effect of $\alpha$-terpinyl acetate on cytochrome P450 2B6 enzymatic activity. Chem. Biol. Interact 2018, 289, 90-97.

46. Rahman, M.K.; Chowdhury, M.A.; Islam, M.T.; Chowdhury, M.A.; Uddin, M.E.; Sumi, C.D. Evaluation of Antidiarrheal Activity of Methanolic Extract of Maranta arundinacea Linn. Leaves. Adv. Pharmacol. Sci. 2015, 2015, 257057.

47. Chadwick, M.; Trewin, H.; Gawthrop, F.; Wagstaff, C. Sesquiterpenoids lactones: Benefits to plants and people. Int. J. Mol. Sci. 2013, 14, 12780-12805. [CrossRef]

48. NIST: National Institute of Standards and Technologies, Mass Spectra Libraries. Available online: http://www.sisweb.com/ software/nist-gc-library.htm (accessed on 15 February 2020).

49. Mith, H.; Duré, R.; Delcenserie, V.; Zhiri, A.; Daube, G.; Clinquart, A. Antimicrobial activities of commercial essential oils and their components against food-borne pathogens and food spoilage bacteria. Food Sci. Nutr. 2014, 2, 403-416.

50. CLSI. Performance Standards for Antimicrobial Disk Susceptibility Test. Approved Standard M02-A10, 10th ed.; Clinical and Laboratory Standards Institute, CLSI: Wayne, PA, USA, 2009; Volume 29, p. 1.

51. Kang, J.M.; Liu, L.; Wu, X.X.; Sun, Y.Y.; Liu, Z.F. Effect of thyme essential oil against Bacillus cereus planktonic growth and biofilm formation. Appl. Microbiol. Biotechnol. 2018, 102, 10209-10218.

52. NRC (National Research Council). Guide for the Care and Use of Laboratory Animals, 8th ed.; National Academies Press: Washington, DC, USA, 2011.

53. Kilkenny, C.; Browne, W.J.; Cuthill, I.C.; Emerson, M.; Altman, D.G. Improving bioscience research reporting: The ARRIVE guidelines for reporting animal research. PLoS Boil. 2010, 8, e1000412.

54. Rehman, N.U.; Ansari, M.N.; Samad, A. In Silico, Ex Vivo and In Vivo Studies of Roflumilast as a Potential Antidiarrheal and Antispasmodic agent: Inhibition of the PDE-4 Enzyme and Voltage-gated Ca++ ion Channels. Molecules 2020, 25, 1008. [CrossRef] [PubMed]

55. Shah, A.J.; Begum, S.; Hassan, S.I.; Ali, S.N.; Siddiqui, B.S.; Gilani, A.H. Pharmacological basis for the medicinal use of Psidium guajava leave in hyperactive gut disorders. Bangl. J. Pharmacol. 2011, 6, 100-105. 